young DI rats than in young SD rats and adult DI and SD rats. We also found that this hypotension could be prevented by the continuous infusion of AVP $\left(2000 \mathrm{pg} \cdot 100 \mathrm{~g}^{-1} \mathrm{~min}^{-1}\right)$. The adult DI rats were more resistant to hemorrhagic hypotension than the infant DI rats. The reason for this is not known. In addition to AVP, angiotensin has also been thought to prevent hemorrhagic hypotension. The angiotensin levels were the same in the adult DI and SD rats both during control conditions and following bleeding. It is therefore likely that the relative resistance to hemorrhagic hypotension, observed in adult DI rats, is independent of angiotensin.

The serum AVP levels were measured in the SD rats. The capacity to release AVP was at least as good in young as in adult rats. Previous studies on fetal lambs have shown that the capacity to release AVP in response to blood volume contraction is well developed even in fetal life (12). The AVP levels recorded under basal conditions were high in both the adult and the infant DI rats; they were 21 and $45 \mathrm{pg} \cdot \mathrm{ml}^{-1}$, respectively. In adult rats that have been dehydrated for $48 \mathrm{~h}$, the AVP concentration has been reported to be around $30 \mathrm{pg} \cdot \mathrm{ml}^{-1}(5)$. The SD rats in this study had been dehydrated for $10 \mathrm{~h}$ and subjected to anesthesia and blood vessel cannulation which might have caused the blood volume contraction. Great care had, however, been taken not to use animals that had been bled prior to carrying out the procedure. Following bleeding, the AVP levels increased in both groups, but the increase was significant only in the adult rats. It is possible, however, that the AVP levels in the infant rats were already so high during basal conditions that they represented maximal levels.

\section{REFERENCES AND NOTES}

1. Aperia A, Herin P 1975 Development of glomerular perfusion rate and nephron filtration rate in rats 17-60 days old. Am J Physiol 228:1319

2. Ausiello D, Kreisberg J, Roy C, Karnosky M 1980 Contraction of cultured rat glomerular cells of apparent mesangial origin after stimulation with angiotensin II and arginine vasopressin. J Clin Invest 65:754
3. Claybaugh JR, Share L 1973 Vasopressin, renin and cardiovascular responses to continuous slow hemorrhage. Am J Physiol 224:519

4. Cowley AW Jr, Switzer SJ, Guinn MM 1980 Evidence and quantification of the vasopressin arterial pressure control system in the dog. Circ Res 46:58

5. Fyhrquist F, Tikkanen I, Linkola J 1981 Plasma vasopressin concentration and renin in the rat: Effect of hydration and hemorrhage. Acta Physiol Scand 113:507

6. Hall CE, Ayachi S, Hall SA 1973 Spontaneous hypertension in rats with hereditary hypothalamic diabetes insipidus. Tex Rep Biol Med 31:471

7. Laycock JF, Penn W, Shirley DG, Walter SJ 1979 The role of vasopressin in blood pressure regulation immediately following acute hemorrhage in the rat. J Physiol 296:267

8. Montani J-P, Liard J-F, Schoun J, Möhring J 1980 Hemodynamic effects of exogenous and endogenous vasopressin at low plasma concentrations in conscious dogs. Circ Res 47:346

9. Pohjavuori M, Fyhrquist F 1980 Hemodynamic significance of vasopressin in the newborn infant. J Pediatr 97:462

10. Pullan PT, Johnston CI, Anderson WP, Korner PI 1980 Plasma vasopressin in blood pressure homeostasis and in experimental renal hypertension. Am J Physiol 239:H81

11. Rees L, Forsling ML, Brook CG 1980 Vasopressin concentrations in the neonatal period. Clin Endocrinol 12:357

12. Robillard JE, Weitzman RE, Fisher DA, Smith FG Jr, 1979 The dynamics of vasopressin release and blood volume regulation during fetal hemorrhage in the lamb fetus. Pediatr Res 13:606

13. Schlondorff D, Weber H, Trizna H, Fine LG 1978 Vasopressin responsiveness of renal adenylate cyclase in newborn rats and rabbits. Am J Physiol 234:F16

14. Schrier RW, Berl T, Anderson RJ 1979 Osmotic and nonosmotic control of vasopressin release. Am J Physiol 236:F321

15. Svenningsen NW, Aronson AS 1974 Postnatal development of renal concentration capacity, as estimated by DDAVP test in normal and asphyxiated neonates. Biol Neonate 25:230

16. Valtin H 1976 Animal model of human disease: hereditary hypothalamic diabetes insipidus. Am J Pathol 83:633

17. Weitzman RE, Reviczky A, Oddie TH, Fisher DA 1980 Effect of osmolality on arginine vasopressin and renin release after hemorrhage. Am J Physiol 238:E62

18. This research was supported by grants from the Swedish Medical Research Council (06263) and from the Expressen Newspaper Prenatal Fund. The preliminary results of this study were presented at the Symposium on the Brattleboro Rat in the U. S. A., September 1981.

19. Requests for reprints should be addressed to: Peter Herin, Department of Pediatrics, St Göran's Hospital, Box 12500, S-112 81 Stockholm, Sweden.

20. Received for publication October $25,1983$.

\title{
Abnormal Fatty Acid Turnover in the Phospholipids of the Red Blood Cell Membranes of Cystic Fibrosis Patients (in Vitro Study)
}

\author{
VERA ROGIERS ${ }^{(28)}$, ISIDOOR DAB, YVETTE MICHOTTE, ANTOINE VERCRUYSSE, \\ ROBERT CROKAERT, AND HENRI L. VIS \\ Department of Pharmacognosy, Phytochemistry and Toxicology [V. R., A. V.], Department of Pediatrics [I. D., \\ H. L. V.], Department of Pharmaceutical and Biomedical Analyses [Y. M.], and Department of Biochemistry \\ [R. C.], Free University of Brussels, Laarbeeklaan, 103, B-109 Brussels, Belgium
}

\section{Summary}

A study was carried out in order to investigate whether the abnormal in vitro turnover of fatty acids in the phospholipids of the red blood cell membranes of cystic fibrosis patients is intrinsic to the membrane, or whether it is induced by extrinsic serum factors. Red blood cells of cystic fibrosis patients and healthy subjects were labeled in vitro with $\left[{ }^{14} \mathrm{C}\right]$ linoleic acid, bound to albumin. The labeled cells were reincubated in autologous and homologous serum. The radioactivity present in the serum lipids and in the major phospholipid fractions of the red cell membranes was measured.

Conclusions of this study are: 1) not all of the cystic fibrosis patients examined individually show an abnormal in vitro turnover of the red cell fatty acids, although they all presented abnormal fatty acid patterns for the red blood cell phospholipids, 
the platelet phospholipids, and the plasma lipids. 2) The in vitro abnormal fatty acid turnover occurs only in the incubations where red cells of cystic fibrosis patients are involved (in homologous and autologous serum) and not where red cells of healthy subjects are incubated in serum of cystic fibrosis patients. Consequently, the abnormal turnover is intrinsic to the red cells and is not induced by extrinsic serum factors.

\section{Abbreviations}

\author{
FA, fatty acid \\ CF, cystic fibrosis \\ RBC, red blood cell \\ PC, phosphatidylcholine \\ PE, phosphatidylethanolamine
}

From a review of the literature, it is clear that the FA patterns of the lipid fractions of biological fluids and tissues from CF patients are changed in comparison with the corresponding patterns of healthy subjects $(1,2,4,7-9,11,13,14,17-19,21$, 22). Two possible explanations may be given for these abnormal FA patterns: they are due to malabsorption of essential dietary fat $(7,8)$ or a primary defect in FA metabolism could be involved $(13,14)$. The results of our previous research rather support the latter hypothesis. Indeed, it was shown that abnormal FA patterns can occur in both CF patients with and without pancreatic insufficiency $(17,18)$. Furthermore, it was found that the in vitro turnover of FA in the phospholipids of the erythrocyte membranes is significantly higher for CF patients than for healthy children (20). This conclusion has been drawn from in vitro experiments carried out with $\mathrm{RBC}$, radioactively labeled with $\left[{ }^{14} \mathrm{C}\right]$ linoleic and $\left[{ }^{3} \mathrm{H}\right]$ palmitic acid, of $\mathrm{CF}$ patients with pancreatic insufficiency and of healthy children with their own serum (20). This increased in vitro turnover of the FA in the RBC of $\mathrm{CF}$ patients can be intrinsic to the membrane but may also be caused by extrinsic serum factors. Until now, no experiments with standardized serum have been performed in order to try to separate intrinsic from extrinsic effects. The amount of blood to be taken from one CF child (8-10 years old) would have been too high. In this study, however, older CF patients (17-19 years old) were involved so that the amount of blood taken was no longer critical. Incorporation and reincubation experiments with radioactively labeled $\mathrm{RBC}$ of $\mathrm{CF}$ patients and healthy subjects have been carried out not only with autologous serum, but also with homologous serum.

\section{MATERIALS AND METHODS}

Materials used for the analysis of the individual phospholipid fractions of the $\operatorname{RBC}(15,16)$, for the in vitro experiments (20) and for the radioactivity measurements (20) were described previously.

Subjects and blood collection. After an overnight fast of $12 \mathrm{~h}$, $80 \mathrm{ml}$ venous blood was collected with sodium citrate from six CF patients with pancreatic insufficiency (three female and three male, 17-19 years old) and from six healthy subjects of the same age and sex. The healthy subjects had the same bloodgroup as the matched CF patients. Six experiments, each time with RBC and serum of one CF patient and one healthy volunteer, were carried out.

In vitro experiments. The methodology of the in vitro experiments has been described previously in detail (20). In short, blood was centrifuged and the packed RBC were washed. Next, they were incubated for $2 \mathrm{~h}$ with a $\left[{ }^{14} \mathrm{C}\right]$ linoleic acid-labeled albumin solution $\left(0.5 \times 10^{8} \mathrm{dpm} / \mathrm{ml}\right.$ solution) in Krebs-Henseleit buffer containing glucose, ATP, and CoASH. The RBC were sedimented by centrifugation and washed extensively, especially with defatted human albumin solution in order to remove surface fatty acids. The RBC were resuspended for $5 \mathrm{~min}$ in their own serum in order to restore the normal surface pool of nonradio- active FA. After removing the serum, the radioactively labeled RBC were incubated separately with autologous and homologous serum with additives as described (20). At various time intervals, aliquots were taken and centrifuged, and the $\mathrm{RBC}$ were washed and stored with dithionite at $-20^{\circ} \mathrm{C}$. Lipid extracts were prepared the next day and stored at $-20^{\circ} \mathrm{C}$ under $\mathrm{N}_{2}$. The determinations of the individual phospholipid fractions $(16,19)$ and the measurements of the radioactivity (20) were done as described.

The following incubations were carried out: 1) $\mathrm{RBC}$ of $\mathrm{CF}$ patients in their own serum (autologous); 2) RBC of CF patients in serum of healthy subjects (homologous); 3) RBC of healthy subjects in serum of CF patients (homologous); 4) RBC of healthy subjects in their own serum (autologous).

Additional determinations. Serum vitamin $\mathrm{E}$ and $\mathrm{A}$ levels were determined using a high performance liquid chromatography technique (5). The globular resistance was measured using $\mathrm{NaCl}$ solutions with varying concentrations (25). The plasma nonesterified FA pattern (17) and the FA composition of the plasma cholesterol esters (18), the RBC phospholipids (19), and the platelet phospholipids (unpublished data) have been determined by thin layer chromatography-gas chromatography techniques, previously described.

\section{RESULTS}

As for our previous results (20), the theoretical approach, proposed by Shohet and co-workers $(23,24)$ was used. The assumption was made that the incorporated FA are all taken up into PC before their transfer into $\mathrm{PE}$ and their final release into the serum. Again, sphingomyelin was used as internal standard.

Uptake into phosphatidylcholine. The results (mean \pm SD) obtained for the uptake of $\left[{ }^{14} \mathrm{C}\right]$ linoleic acid from a deep membrane pool of nonesterified fatty acids into PC are shown in Table 1. A two-way analysis of variance (26) was applied to these results at the significance level of 0.05 . Both treatments were highly significant $(P<0.001$; the variables are "time" and "combinations"). The mean uptakes in PC, obtained for the four combinations, were compared at the four separate time intervals using a one-way analysis of variance. Significant analyses of variance were followed by Newman-Keuls tests which permitted distinction of homogeneous subsets. The results are indicated in Table 1. From $9 \mathrm{~h}$ on, after the reincubation was started, a significant difference was found $(P<0.02)$. Two homogeneous subsets existed. One was composed of combinations 1 and 2 while combinations 3 and 4 belonged to the second subset. In other words, the mean in vitro uptake of $\left[{ }^{14} \mathrm{C}\right]$ linoleic acid into $\mathrm{PC}$ was for the combinations where $\mathrm{RBC}$ of CF patients were involved significantly different from the one measured for the combinations where $\mathrm{RBC}$ of healthy subjects were used. No significant difference was observed between the results for combinations 1 and 2, or between those for combinations 3 and 4 . This means that the serum used in these experiments had no effect on the abnormal incorporation of $\left[{ }^{14} \mathrm{C}\right]$ linoleic acid into the PC fraction of the RBC membranes of CF patients. The observation that the mean uptake for combination 1 is higher than the one for combination 4 is only a confirmation of our previous results (20). In Figure 1, the individual uptake of $\left[{ }^{14} \mathrm{C}\right]$ linoleic acid into PC is shown for the six experiments. It is not possible to distinguish the uptake of patient 6 from the corresonding value of the normal control. The experiment was redone on RBC of the same CF patient but with $R B C$ and the serum of two more volunteers with the same bloodgroup. However, identical results were obtained.

Transfer into phosphatidylethanolamine. In Table 2, the results obtained for the in vitro transfer of labeled linoleic acid from PC into PE is shown. A two-way analysis of variance shows highly significant effects of both variables (time and combinations) $(P$ $<0.001$ ). From $9 \mathrm{~h}$ on, two homogeneous subsets existed (combinations 1 and 2; combinations 3 and 4). Since these observations are similar to those made before, the same conclusions can 
Table 1. In vitro incorporation of $\left[{ }^{14} \mathrm{Cllinoleic}\right.$ acid into the phosphatidylcholine fraction of $R B C$ membranes during incubations of: 1) $R B C$ of $C F$ patients in their own serum (autologous serum); 2) $R B C$ of $C F$ patients in homologous serum of healthy subjects; 3) $R B C$ of healthy subjects in homologous serum of $C F$ patients; 4) RBC of healthy subjects in autologous serum*

\begin{tabular}{|c|c|c|c|c|c|}
\hline \multirow{3}{*}{$\begin{array}{c}\text { Time } \\
\text { (h) }\end{array}$} & \multicolumn{4}{|c|}{$\mathrm{dpm} \mathrm{PC} / \mathrm{ml} \mathrm{RBC}($ mean $\pm \mathrm{SD})$} & \multirow{3}{*}{$\begin{array}{c}\text { One-way analysis } \\
\text { of variance }\end{array}$} \\
\hline & \multicolumn{4}{|c|}{ Combinations } & \\
\hline & 1 & 2 & 3 & 4 & \\
\hline 0 & $723,527 \pm 119,549$ & $764,092 \pm 213,734$ & $705,088 \pm 112,515$ & $730,415 \pm 143,971$ & $\begin{array}{l}\text { NS } \\
1 \text { subset }\end{array}$ \\
\hline 4 & $1,365,549 \pm 206,296$ & $1,481,641 \pm 378,481$ & $1,106,287 \pm 129,858$ & $1,187,994 \pm 164,277$ & $\begin{array}{l}\text { NS } \\
1 \text { subset }\end{array}$ \\
\hline 9 & $1,719,768 \pm 423,871$ & $1,958,687 \pm 468,943$ & $1,344,974 \pm 173,267$ & $1,436,035 \pm 159,365$ & $\begin{array}{l}p<0.02 \\
2 \text { subsets }\end{array}$ \\
\hline 11 & $1,877,701 \pm 467,674$ & $2,051,956 \pm 524,249$ & $1,444,882 \pm 196,605$ & $1,490,476 \pm 196,030$ & $\begin{array}{l}p<0.03 \\
2 \text { subsets }\end{array}$ \\
\hline
\end{tabular}

* Statistical significance is indicated (one-way analysis of variance at every time interval); NS, not significant.
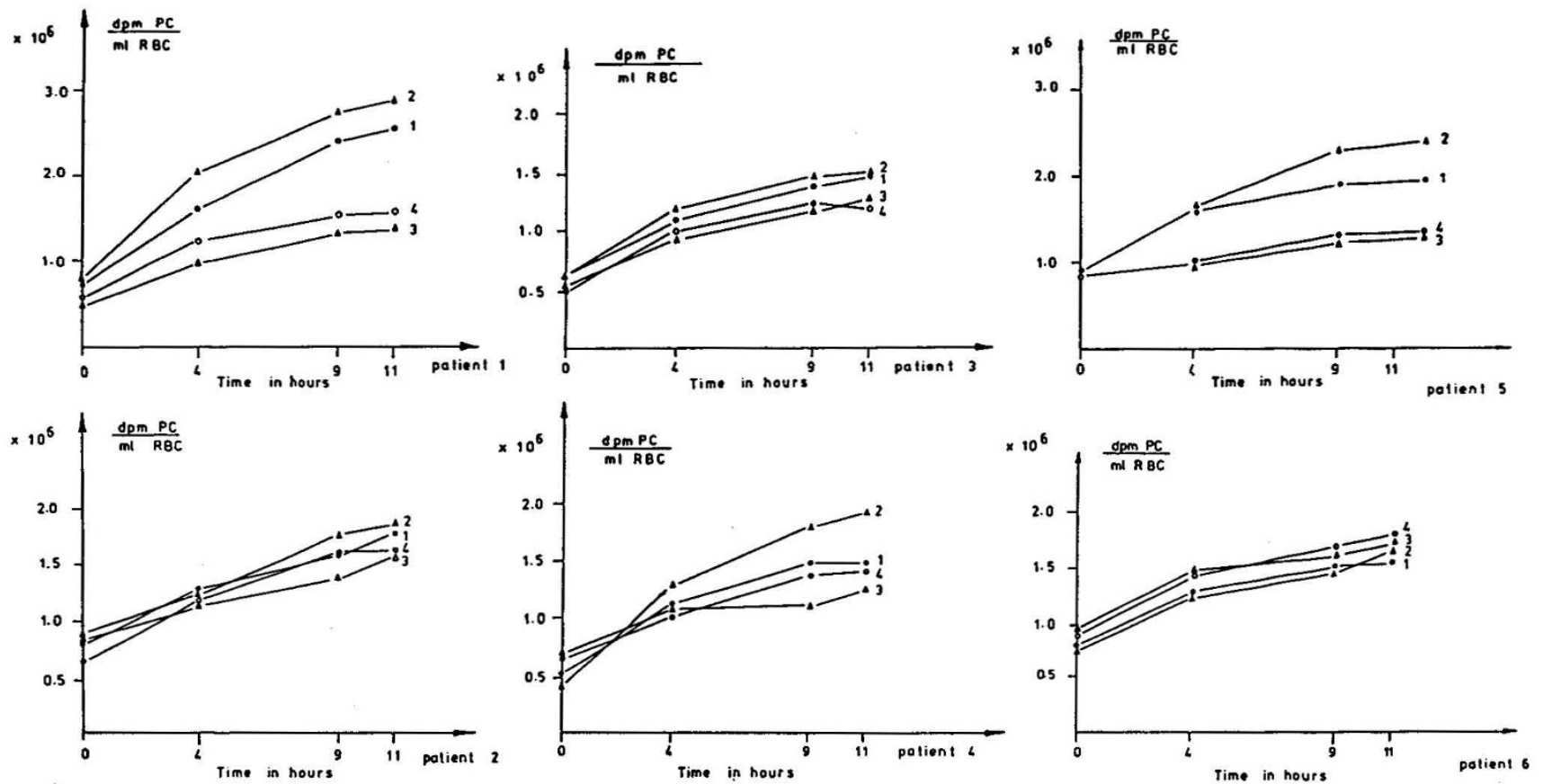

Fig. 1. In vitro incorporation of $\left[{ }^{14} \mathrm{C}\right]$ linoleic acid into the phosphatidylcholine fraction of $\mathrm{RBC}$ membranes. The results are shown individually for the six CF patients and the healthy subjects studied. The experimental conditions are as described in "Materials and Methods." $\bullet$, Incubation of RBC of CF patients in their own serum (combination 1); $O$, incubation of RBC of matched healthy subjects in their own serum (combination 4); $\Delta$, incubation of RBC of CF patients in homologous serum of matched healthy subjects (combination 2); $\triangle$, incubation of RBC of healthy subjects in homologous serum of matched CF patients (combination 3).

Table 2. In vitro transfer of $\left[{ }^{14} \mathrm{C}\right]$ linoleic acid from the phosphatidylcholine into the phosphatidylethanolamine fraction of $R B C^{*}$ membranes

\begin{tabular}{|c|c|c|c|c|c|}
\hline \multirow{3}{*}{$\begin{array}{c}\text { Time } \\
\text { (h) }\end{array}$} & \multicolumn{4}{|c|}{$\mathrm{dpm} \mathrm{PE} / \mathrm{ml} \mathrm{RBC}($ mean $\pm \mathrm{SD})$} & \multirow{3}{*}{$\begin{array}{c}\text { One-way analysis } \\
\text { of variance }\end{array}$} \\
\hline & \multicolumn{4}{|c|}{ Combinations } & \\
\hline & 1 & 2 & 3 & 4 & \\
\hline 0 & $255,411 \pm 42,303$ & $256,920 \pm 56,433$ & $237,705 \pm 28,069$ & $230,083 \pm 24,259$ & $\begin{array}{l}\text { NS } \\
1 \text { subset }\end{array}$ \\
\hline 4 & $972,587 \pm 202,666$ & $1,087,360 \pm 346,653$ & $729,635 \pm 55,835$ & $762,071 \pm 94,996$ & $\begin{array}{l}\text { NS } \\
1 \text { subset }\end{array}$ \\
\hline 9 & $1,352,505 \pm 383,212$ & $1,546,544 \pm 463,861$ & $1,015,448 \pm 96,847$ & $1,051,095 \pm 125,113$ & $\begin{array}{l}p<0.02 \\
2 \text { subsets }\end{array}$ \\
\hline 11 & $1,477,638 \pm 425,301$ & $1,652,312 \pm 495,495$ & $1,081,933 \pm 143,708$ & $1,109,372 \pm 130,829$ & $\begin{array}{l}p<0.02 \\
2 \text { subsets }\end{array}$ \\
\hline
\end{tabular}

* The abbreviations are as given in Table 1 .

be drawn. Again, only five of the six patients studied showed individually an abnormal transfer of FA into PE.

Release into serum. The in vitro release of $\left[{ }^{14} \mathrm{C}\right]$ linoleic acid from the RBC into autologous and homologous serum went on during the whole experiment (Fig. 2 and Table 3). From $9 \mathrm{~h}$ on, the mean release of labeled linoleic acid into serum was significantly higher for combinations 1 and 2 than for 3 and $4(P<$ 0.02 , one-way analysis of variance). It is clear that no difference 

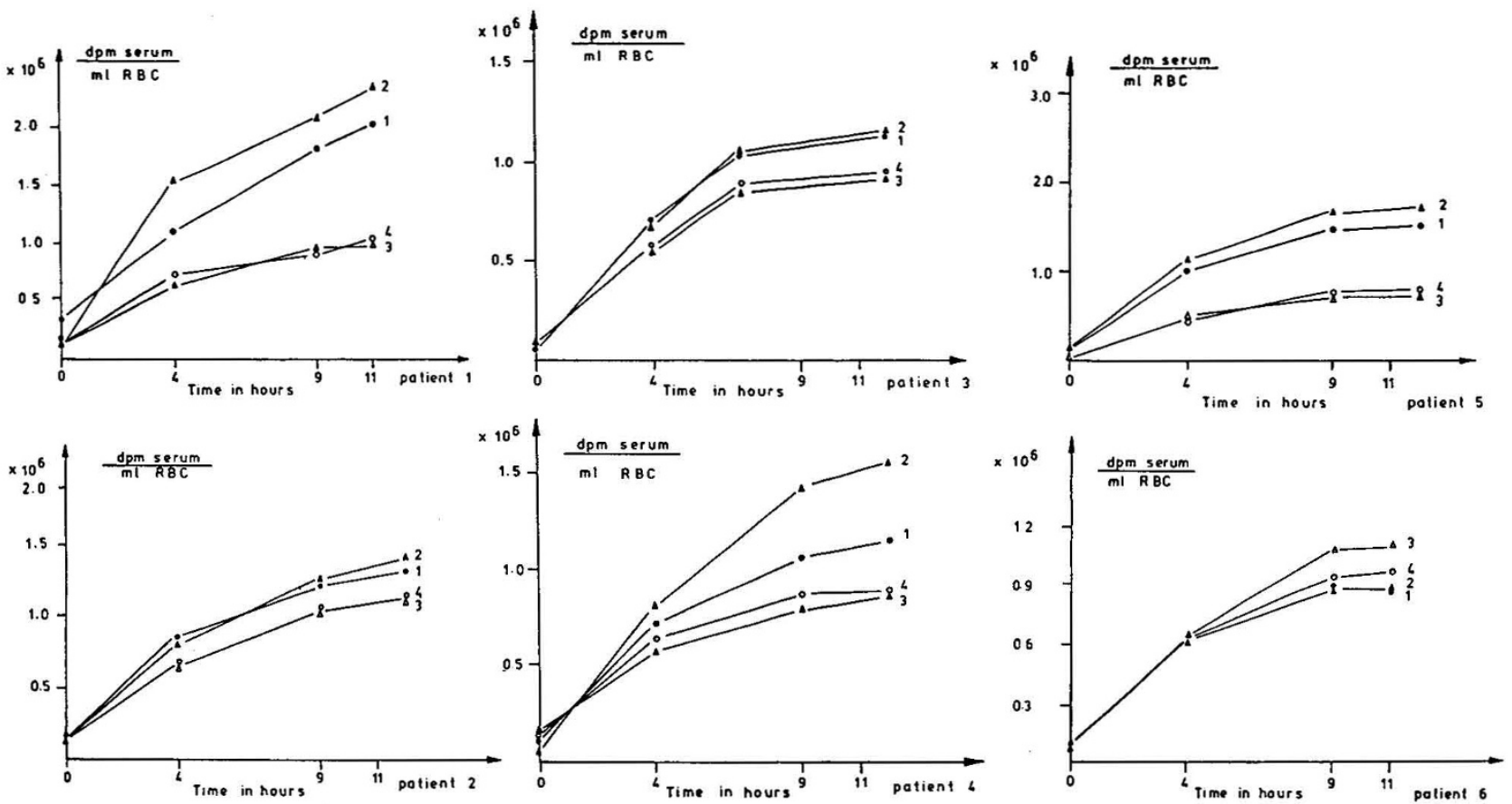

Fig. 2. In vitro release of $\left[{ }^{14} \mathrm{C}\right]$ linoleic acid from phosphatidylethanolamine into serum. The results are shown individually for the six $\mathrm{CF}$ patients and the healthy subjects studied. The experimental conditions are as described in "Materials and Methods." $\bullet$, Incubation of RBC of CF patients in their own serum (combination 1); $O$, incubation of $R B C$ of matched healthy subjects in their own serum (combination 4); $\Delta$, incubation of $R B C$ of CF patients in homologous serum of matched healthy subjects (combination 2); $\triangle$, incubation of RBC of healthy subjects in homologous serum of matched CF patients (combination 3).

Table 3. In vitro release of $\left[{ }^{14} \mathrm{Cllinoleic}\right.$ acid from phosphatidylethanolamine into serum

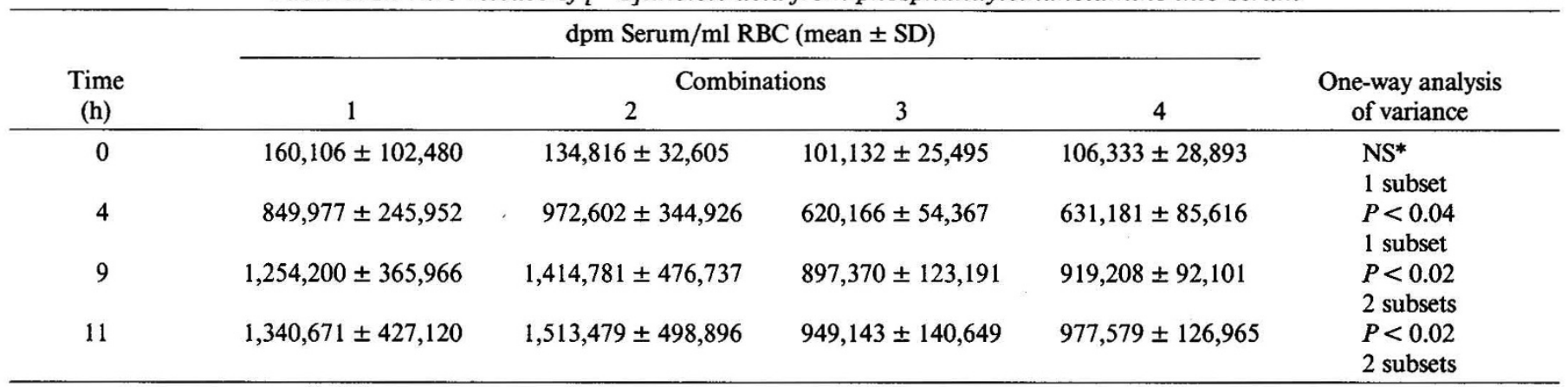

${ }^{*}$ NS, not significant.

can be observed between combinations 1 and 2, and between 3 and 4 (combinations 1 and 2 form a homogeneous subset, while 3 and 4 form another one). Again, the RBC of one CF patient show normal behavior: namely, a normal release of $\left[{ }^{14} \mathrm{C}\right]$ linoleic acid from the $\mathrm{RBC}$ into autologous and homologous serum was measured (Fig. 2).

Additional determinations. The results for serum vitamin $\mathrm{E}$ and vitamin A and for globular resistance are shown in Table 4. No correlation could be observed between the serum vitamin $\mathrm{E}$ concentration of the CF patients and the degree of abnormality of the FA turnover in the RBC. Furthermore, there was no difference between the globular resistance of the CF patients and the healthy controls. Therefore, it is not obvious that the changes in FA turnover observed for the CF patients are caused by vitamin $\mathrm{E}$ deficiency as described by some investigators $(6,10$, 12).

The FA compositions of the RBC, platelet, and plasma lipids for healthy subjects and for CF patient 6 are shown in Table 5. The patterns for this particular CF patient are abnormal and are in the range of the measurements done before for a group of $\mathrm{CF}$ patients with pancreatic insufficiency (17-19).
Table 4. Serum vitamin $E$ and $A$ concentrations and globular resistance for $C F$ patients and healthy controls (mean $\pm S D$ )

\begin{tabular}{lcccc}
\hline & $\begin{array}{c}\text { Serum } \\
\text { vitamin E }\end{array}$ & $\begin{array}{c}\text { Serum } \\
\text { vitamin A }\end{array}$ & \multicolumn{2}{c}{ Hemolysis $(\% \mathrm{NaCl})$} \\
\cline { 4 - 6 }$(\mu \mathrm{g} / \mathrm{ml})$ & $(\mu \mathrm{g} / \mathrm{ml})$ & First & Complete \\
\hline Healthy $(n=6)$ & $7.5 \pm 1.4$ & $0.97 \pm 0.10$ & $0.45 \pm 0.02$ & $0.34 \pm 0.02$ \\
CF $(n=6)$ & $4.4 \pm 2.5$ & $0.90 \pm 0.02$ & $0.45 \pm 0.02$ & $0.34 \pm 0.01$ \\
\hline
\end{tabular}

\section{DISCUSSION}

The experiments described here were done with one labeled fatty acid, namely $\left[{ }^{14} \mathrm{C}\right]$ linoleic acid, because no difference was detectable between the in vitro behavior of $\left[{ }^{14} \mathrm{C}\right]$ linoleic versus $\left[{ }^{3} \mathrm{H}\right]$ palmitic acid in $\mathrm{CF}$ patients compared with healthy subjects (20). No extra precautions were taken to be sure that the healthy subjects studied were not possible CF heterozygotes. It has been shown before $(20)$ that no significant difference could be observed for the FA turnover in obligate CF heterozygotes and healthy subjects.

The results of this study are generally a confirmation of our 
Table 5. FA composition of RBC, platelet (PC fraction) and plasma lipids [nonesterified fatty acids (NEFA) and cholesterol esters] for healthy subjects and for $C F$ patient $6^{*}$

\begin{tabular}{|c|c|c|c|c|c|c|c|c|}
\hline & \multicolumn{2}{|c|}{$\begin{array}{c}\text { RBC } \\
\text { PC fraction (21) }\end{array}$} & \multicolumn{2}{|c|}{$\begin{array}{c}\text { Platelets } \\
\text { PC fraction } \\
\text { (unpublished data) }\end{array}$} & \multicolumn{2}{|c|}{$\begin{array}{c}\text { Plasma } \\
\text { NEFA fraction (20) }\end{array}$} & \multicolumn{2}{|c|}{$\begin{array}{c}\text { Plasma } \\
\text { cholesterol esters (19) }\end{array}$} \\
\hline & Healthy $(n=12)$ & CF 6 & Healthy $(n=6)$ & CF 6 & Healthy $(n=61)$ & CF 6 & Healthy $(n=10)$ & CF 6 \\
\hline $\mathrm{C}_{16: 0}$ & $34.1 \pm 2.0$ & 36.3 & $39.2 \pm 2.5$ & 39.7 & $25.3 \pm 2.5$ & 36.7 & $9.9 \pm 0.9$ & 15.0 \\
\hline$C_{16: 1}$ & & & Traces & 4.1 & $5.4 \pm 2.3$ & 2.5 & $3.1 \pm 0.6$ & 8.8 \\
\hline $\mathrm{C}_{18: 0}$ & $12.3 \pm 0.7$ & 10.7 & $16.2 \pm 1.3$ & 11.2 & $10.4 \pm 2.3$ & 7.4 & $2.1 \pm 0.4$ & 6.5 \\
\hline $\mathrm{C}_{18: 1 \omega 9}$ & $19.4 \pm 0.9$ & 21.8 & $20.9 \pm 0.7$ & 23.2 & $37.5 \pm 3.5$ & 35.9 & $16.9 \pm 2.3$ & 16.6 \\
\hline $\mathrm{C}_{18: 2 \omega 6}$ & $21.5 \pm 1.7$ & 15.5 & $12.2 \pm 2.2$ & 6.2 & $17.6 \pm 4.3$ & 12.5 & $56.1 \pm 4.0$ & 41.7 \\
\hline $\mathrm{C}_{20: 3 \omega 6}$ & $1.9 \pm 0.4$ & 3.0 & & & & & & \\
\hline $\mathrm{C}_{20: 4 \omega 6}$ & $5.2 \pm 0.9$ & 6.8 & $12.5 \pm 1.9$ & 15.6 & & & $7.2 \pm 2.0$ & 7.3 \\
\hline $\mathrm{C}_{22: 4 \omega 6}$ & $0.6 \pm 0.3$ & 0.6 & & & & & & \\
\hline
\end{tabular}

* The results are expressed as percentage of total FA; for healthy subjects, the mean \pm SD is presented.

previous findings (20). However, an important additional observation is the fact that not all of the $\mathrm{CF}$ patients examined individually show abnormal in vitro behavior of their RBC. Of the $10 \mathrm{CF}$ patients examined so far, nine showed individually an increased FA turnover. The RBC of one CF patient (patient 6) had completely normal in vitro behavior in our experiments. This CF patient suffered from pancreatic insufficiency but his general condition was very good in comparison with the other CF patients studied. One wonders what might be different in this patient. From the results of Table 5, it would not seem that it is a simple matter of FA concentrations.

The increased in vitro FA turnover can be intrinsic to the membranes or may be caused by extrinsic serum factors. From the results (Figs. 1 and 2), it appears that the abnormality occurs only in those incubations where RBC of CF patients are involved (combinations 1 and 2) and not where RBC of healthy subjects are incubated in serum of CF patients (combination 3). Consequently, it may be concluded that the abnormal FA turnover, occurring in the RBC phospholipids of most CF patients, is intrinsic to the RBC and is not induced by extrinsic serum factors. Unfortunately, the results obtained here cannot be compared with data in the literature, because as far as we know, they are not available. The only study which has some relation with our own work is the study by Chase et al. (3). They reported that under some conditions CF fibroblasts cultured with $\left[{ }^{14} \mathrm{C}\right]$ linoleic acid in different media were able to incorporate more radioactivity into their phospholipids than controls.

An increased FA turnover in the RBC is clearly present in nine of the $10 \mathrm{CF}$ patients examined, but no in all of them. It remains necessary to study more subjects, especially in relation to the state of their disease. An important question must be answered: namely, if this abnormality is also detectable in CF patients without pancreatic insufficiency. It is worthwhile to follow up a number of $\mathrm{CF}$ patients in order to detect any correlation between the FA composition of the plasma and RBC lipids, the in vitro FA turnover of the $\mathrm{RBC}$, and the evolution of the disease. Furthermore, it would be of great interest to study patients with essential fatty acid deficiency, thus controls with low lipid levels of linoleic and linolenic acids. If the FA turnover of the RBC of CF patients were still higher, our results would be more suggestive of a primary defect.

\section{REFERENCES AND NOTES}

1. Burns GB, Dodge JA 1982 Elevated levels of 13,14-dihydro-15-ketoprostaglandin metabolites and essential fatty acid deficiency in CF and heterozygote subjects. In: Baran D (ed) Proceedings of the 11 th Annual Meeting of the European Working Group on Cystic Fibrosis, June 1982, Brussels, Belgium ACCO, Leuven, Belgium, p 76

2. Caren R, Corbo L 1966 Plasma fatty acids in pancreatic cystic fibrosis and liver disease. J Clin Endocrinol 26:470
3. Chase HP, Dabiere CS, Elliott RB 1980 Fibroblast fatty acids in cystic fibrosis. Metabolism 29:365

4. Chase EP, Dupont J 1978 Abnormal levels of prostaglandins and fatty acids in blood of children with cystic fibrosis. Lancet 2:236

5. De Leenheer AP, De Bevere VORC, De Ruyter MGM, Claeys AE 1979 Simultaneous determination of retinol and $\alpha$-tocopherol in human serum by high-performance liquid chromatography. J Chromatogr 162:408

6. Farrell PM, Bieri JG, Fratantoni JF, Wood RE, di Sant'Agnese PA 1977 The occurrence and effects of human vitamin E deficiency. J Clin Invest 60:233

7. Galabert C, Filliat M, Chazalette JP 1978 Fatty-acid composition of serumlecithins in cystic fibrosis patients without steatorrhoea. Lancet 2:903

8. Hubbard VS, Dewey Dunn G, di Sant'Agnese PA 1977 Abnormal fatty-acid composition of plasma-lipids in cystic fibrosis. A primary or a secondary defect? Lancet 2:1302

9. Kuo PT, Huang NN, Bassett DR 1962 The fatty acid composition of the serum chylomicrons and adipose tissue of children with cystic fibrosis of the pancreas. J Pediatr 60:395

10. Lubin BH, Shohet SB 1970 Alterations in membrane fatty acid turnover in vitamin E deficient erythrocytes during exposure to hydrogen peroxide. Pediatr Res 4:466

11. McEvoy FA 1975 Essential fatty acids and cystic fibrosis. Lancet 2:236

12. Oliveira M, Nason A 1968 Vitamin E deficiency and fatty acid turnover in erythrocyte membranes. Biochim Biophys Acta 150:319

13. Robinson PG 1976 5,8-11-Eicosatrienoic acid in red cells from patients with cystic fibrosis. In: l'association française de lutte coutre la mucoviscidose (ed). Proceedings of the 7th International Cystic Fibrosis Congress, Paris, France, pp 107-110

14. Robinson PG, Dodge JA 1980 Blood cell fatty acids in cystic fibrosis. In: Sturgess JM (ed): The Imperial Press Ltd., Ontario, Canada, p 31a Perspectives in Cystic Fibrosis, Proceedings of the 8th International Cystic Fibrosis Congress, Toronto, Canada, May 26-30, 1980

15. Rogiers V 1977 The application of an improved gas-liquid chromatographic method for the determination of the long chain non-esterified fatty acid pattern of blood plasma in children. Clin Chim Acta 78:227

16. Rogiers V 1980 Gas chromatographic determination of the fatty acid pattern of red cell membrane plasmalogens in healthy children. J Chromatogr 182:27

17. Rogiers V, Dab I, Crokaert R, Vis HL 1980 Long chain nonesterified fatty acid pattern in plasma of cystic fibrosis patients and their parents. Pediatr Res 14:1088

18. Rogiers V, Vercruysse A, Dab I, Baran D 1983 Abnormal fatty acid pattern of the plasma cholesterol ester fraction in cystic fibrosis patients with and without pancreatic insufficiency Eur J Pediatr, 141:39.

19. Rogiers V, Crokaert R, Vis HL 1980 Altered phospholipid composition and changed fatty acid pattern of the various phospholipid fractions of red cell membranes of cystic fibrosis children with pancreatic insufficiency. Clin Chim Acta 105:105

20. Rogiers V, Mandelbaum I, Mozes N, Vertongen F, Dab I, Crokaert R, Vis HL 1982 "In vitro" study of the incorporation and transport of non-esterified fatty acids into the red blood cell membranes of cystic fibrosis patients. Pediatr Res 16:761

21. Sahu S, Lynn WS 1977 Lipid composition of airway secretions from patients with asthma and with cystic fibrosis. Am Rev Resp Dis 115:233

22. Sanjurjo P, Allue X, Rodriguez-Soriano J 1977 Fatty acid composition of lecithin fraction of mucus in cystic fibrosis. Lancet 1:752

23. Shohet SB 1972 Hemolysis and changes in erythrocyte lipids. N Engl J Med 286:577

24. Shohet SB, Livermore BM, Nathan DG, Jaffee ER 1971 Hereditary hemolytic anemia associated with abnormal membrane lipids: mechanisms of accumulation of phosphatidylcholine. Blood 38:445

25. Van Hauwaert M, De Leenheer A 1969 Basismethoden in de klinische biologie. Gent-Leuven, België, Story-Scientia, pp 215

26. Winer BJ 1970 Statistical Principles in Experimental Design, International Student Edition. New York, McGraw-Hill 
27. This research was supported by the Medical Foundation "Koningin Elisabeth," the "Belgische Vereniging voor Strijd tegen Mucoviscidose," and the "Nationaal Fonds voor Wetenschappelijk Onderzoek" S2/5-I. D. E. 37.

28. Requests for reprints should be addressed to: Vera Rogiers, V. U. B., Laboratorium Farmacognosie en Toxicologie, Laarbeeklaan, 103, B-1090 Brussel, België.
29. The authors thank Labaz, Belgium for the use of their laboratory equipment. G. De Dobbeleer is also thanked for her efficient technical assistance. Finally, we wish to thank the cystic fibrosis patients and the healthy volunteers for their kind cooperation.

30. Received for publication August 13, 1983.

31. Accepted for publication September 30, 1983.

\title{
Metabolic Consequences of Intrauterine Growth Retardation in Very Low Birthweight Infants
}

\author{
PHILLIPPE CHESSEX, ${ }^{45}$ BRIAN REICHMAN, ${ }^{46}$ GASTON VERELLEN, ${ }^{47}$ GUY PUTET, ${ }^{48}$ \\ JOHN M. SMITH, TIBOR HEIM, ${ }^{49}$ and PAUL R. SWYER ${ }^{50}$ \\ Departments of Paediatrics, Nutrition, and Medical Engineering, The University of Toronto, and the Research \\ Institute, The Hospital for Sick Children, Toronto, Ontario, Canada
}

\section{Summary}

By the combination of energy and macronutrient balances, continuous open circuit computerized indirect calorimetry, and anthropometry, we have compared small for gestational age (SGA) and appropriate for gestational age (AGA) very low birthweight infants with respect to metabolizable energy intake (mean \pm SE: $125.9 \pm 2.5$ versus $130.4 \pm 3.5 \mathrm{kcal} / \mathrm{kg} \cdot$ day), energy expenditure $(67.4 \pm 1.3$ versus $62.6 \pm 0.9 \mathrm{kcal} / \mathrm{kg} \cdot$ day $)$, storage of energy and macronutrients and growth. Fourteen studies in six SGA infants (gestational age, $33.1 \pm 0.3$ weeks; birthweight, $1120 \pm 30 \mathrm{~g}$ ) and 22 studies in 13 AGA infants (gestational age, $29.3 \pm 0.4$ weeks; birthweight, $1155 \pm 40$ g) were performed. The SGA infants had a lower absorption of fat (68.7 \pm 3.2 versus $79.7 \pm 1.7 \%)$ and protein $(69.1 \pm 3.2$ versus $83.4 \pm 1.5 \%)$ and hence increased $(P<0.001)$ energy loss in excreta $(29.9 \pm 2.8$ versus $18.2 \pm 1.5 \mathrm{kcal} / \mathrm{kg}$. day). The significant hypermetabolism of SGA infants by $4.8 \mathrm{kcal} / \mathrm{kg}$. day was associated with an increased fat oxidation. Despite lower energy storage, SGA infants were gaining weight $(19.4 \pm 0.9 \mathrm{~g} / \mathrm{kg} \cdot$ day $)$, length $(1.25 \pm$ $0.14 \mathrm{~cm} /$ week $)$, and head circumference $(1.16 \pm 0.9 \mathrm{~cm} /$ week $)$ at higher rates than the AGA group. The energy storage per $\mathrm{g}$ weight gain was lower $(P<0.001)$ in the SGA group $(3.0 \pm 0.14$ versus $4.26 \pm 0.26 \mathrm{kcal})$ reflecting higher water, lower fat $(22.2$ \pm 1.8 versus $33.8 \pm 2.5 \% ; P<0.001)$ and lower protein $(7.7 \pm$ 0.5 versus $12.5 \pm 0.8 \% ; P<0.001)$ contents of weight gain in the SGA group.

\section{Abbreviations}

SGA, small for gestational age

AGA, appropriate for gestational age

VLBW, very low birth weight

The infant who has suffered from intrauterine malnutrition early in the third trimester of pregnancy is potentially at risk for continued growth retardation $(1,12)$, as well as learning and behavioral problems $(2,13,28)$. These disorders appear to be more prominent among those children whose growth failure began before 26-34 weeks of gestation, in a pregnancy proceeding until near term $(11,16)$. These findings have encouraged the delivery of SGA infants well before term in an attempt to decrease perinatal mortality (41) and to avoid further undernutrition at a critical period of rapid growth rate (42). In order to devise proper feeding regimens for these high risk infants, the metabolic consequences of intrauterine growth retardation need to be understood.

The hypermetabolism of malnourished newborns has been described by a number of authors $(20,33,35)$. However, a quantitative evaluation of the energy metabolism and substrate utilization in SGA infants of VLBW kept on the same diet as AGA matched controls has not been previously documented. We have evaluated and compared the utilization and storage of energy and macronutrients as well as the quality of growth of preterm VLBW SGA and AGA infants.

\section{PATIENTS AND METHODS}

Fourteen studies were undertaken in 6 SGA VLBW $(<1300 \mathrm{~g}$ birth weight) infants. All were below the third percentile at birth for weight, length, and head circumference as determined from Usher's intrauterine growth charts (40). Gestational age was calculated from the mothers' last menstrual period and confirmed by clinical evaluation (10). In four, the growth retardation was due to maternal toxemia or hypertension, and no cause was determined in the remaining two infants. No malformations or intrauterine infections were documented. Three studies were conducted for three of the infants, and in two infants, two studies were performed, at intervals of 1 or 2 weeks. For comparison, 22 studies in 13 AGA VLBW infants of similar birth weight and postnatal age are presented. The clinical characteristics of these two groups of VLBW preterm infants, cared for under the same thermoneutral conditions (19), are shown in Table 1.

Patients selected for this series of studies have met the following criteria: 1) birth weight is less than $1.3 \mathrm{~kg} ; 2$ ) they were either appropriate for gestational age (AGA group) or small for gestational age (SGA group) as assessed from mother's last menstrual period and clinical criteria $(10,40,41) ; 3)$ they were free from congenital anomalies and intrauterine infections; 4) they were 